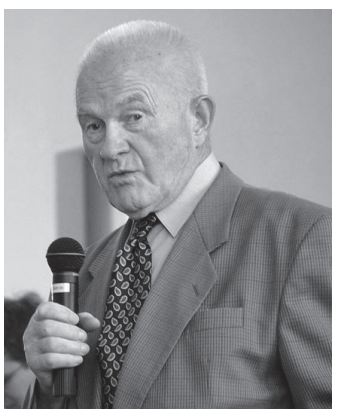

\title{
Odešel profesor Josef Maňák
}

Zprávy o odchodech osobností významných, inspirativních a obohacujících obor, $v$ němž působily, se nepíšou lehce. 0 to těžší je psát o člověku, který byl nejen významným vědcem a učitelem, vyznačujícím se moudrostí a hlubokým porozuměním světu vzdělávání a výchovy, ale také kolegou a přítelem, jenž provázel několik generací českých pedagogů do svého vysokého věku.

Strohá zpráva sděluje, že 6. února 2019 zemřel profesor Josef Maňák v úctyhodném věku 95 let.

Jeho životní dráha se počala na Horňácku, v kraji, který dal svým dětem do vínku poctivost, bojovnost a vytrvalost. Tyto vlastnosti provázely Jožku Maňáka, jak jsme mu mohli k jeho radosti říkat i my mladší, peripetiemi jeho profesního života.

Po desetiletí učitelování pưsobil v šedesátých letech minulého století na univerzitách $\vee$ Olomouci a poté $v$ Brně. Nadějné tvưrčí vědecké a pedagogické období ukončila normalizace. Zákaz pedagogické a publikační činnosti doprovázela funkční degradace, neuznání habilitace a nejistota krátkodobých pracovních smluv. Rok 1989 otevřel novou etapu, v níž se stal Josef Maňák proděkanem Pedagogické fakulty Masarykovy univerzity, vedl katedru pedagogiky a inicioval založení Centra pedagogického výzkumu, které se posléze transformovalo do Institutu výzkumu školního vzdělávání (IVŠV), dnes jednoho z nejprestižnějších pracovišt' pedagogického výzkumu v České republice. Působení profesora Maňáka v IVŠV považují jeho spolupracovníci za důležitý zdroj odborné inspirace, profesní kvality i přátelské sounáležitosti a vzácné lidské podpory. I po odchodu do důchodu zůstal profesor Maňák duchovním otcem a rádcem pro své následovníky, vynikajícím širokým přehledem v oboru a bystrými kritickými postřehy, sdělovanými vždy s laskavostí a vlídnou moudrostí zralého věku.

V této krátké vzpomínce na mimořádnou osobnost nebudu odkazovat na bohatý odborný potenciál a publikační produkci profesora Maňáka, to už učinili jiní (viz číslo 5/2014 časopisu Pedagogická orientace, věnované životnímu jubileu J. Maňáka). Chci zmínit naše odborná a lidská setkávání, která nabyla na intenzitě na přelomu milénia. Tehdy se profesor Maňák stal jedním ze zakladatelů našeho společného projektu - Centra výzkumu školního vzdělávání. V něm uplatnil svůj pedagogický a didaktický potenciál staršího a zkušenějšího partnera. Účastnil se, ač již ne zcela zdráv, našich společných aktivit a výjezdních zasedání, vždy připraven přispět obohacujícími komentáři i přátelskou kritikou. Stál také u zrodu tohoto časopisu a ně- 
132 kolik let byl aktivním členem jeho redakční rady. Už jako emeritní profesor zůstával $\checkmark$ kontaktu s redakcí, psal recenze a přispíval do diskuse.

Česká školní pedagogika a didaktika ztrácejí velkou osobnost, avšak myšlenkový odkaz a pedagogický étos profesora Josefa Maňáka, k němuž se hlásíme a na nějž vědomě navazujeme $\mathrm{s}$ obdivem $\mathrm{k}$ noblesnímu člověku a význačnému odborníkovi, zůstávají s námi.

Eliška Walterová eliska.walterova@pedf.cuni.cz 